\title{
SOCIAL SECURITY \\ AND ECONOMIC PERFORMANCE IN PORTUGAL: AFTER ALL THAT HAS BEEN SAID AND DONE HOW MUCH HAS ACTUALLY CHANGED?*
}

\author{
Alfredo Marvão Pereira \\ The College of William and Mary and Universidade do Algarve \\ Jorge M. Andraz \\ Universidade do Algarve
}

College of William and Mary

Department of Economics

Working Paper Number 81

Current Version: October 2011

Previous Version: January 2009

(*) We would like to thank Rui M. Pereira for his research assistance an anonymous referee as well as the Journal Editor for very useful comments and suggestions. The second author would like to acknowledge financial support from the Portuguese Science Foundation (grant ref. PTDC/ECO/64595/2006). 
COLLEGE OF WILLIAM AND MARY

DEPARTMENT OF ECONOMICS

WORKING PAPER \# 81

October 2011

\title{
SOCIAL SECURITY \\ AND ECONOMIC PERFORMANCE IN PORTUGAL: \\ AFTER ALL THAT HAS BEEN SAID AND DONE HOW MUCH HAS ACTUALLY CHANGED?
}

\begin{abstract}
This paper provides an empirical estimate of the macroeconomic effects of the Portuguese payas-you-go social security system based on data for the period 1970-2007 and on VAR estimates using GDP, the unit cost of labor, the unemployment rate, the savings rate and social security spending. The major findings are twofold. First, growing social security spending has had detrimental effects on all of the private sector variables under consideration suggesting the existence of sizable inefficiencies. Second, these inefficiencies persist despite the successive reforms that took place over the last two decades. As a corollary, these results highlight the need for structural reforms of the pay-as-you-go system thereby addressing the sources of inefficiencies in addition to dealing with its chronic sustainability problems.
\end{abstract}

JEL Codes: C32, C51, C52, H55

Keywords: Social security, employment, saving, VAR, Portugal.

Alfredo Marvão Pereira

Department of Economics, The College of William and Mary, Williamsburg, USA

CASEE - Center for Advanced Studies in Economics and Econometrics, Universidade do Algarve, Portugal

ampere@wm.edu

Jorge M. Andraz

Faculdade de Economia, Universidade do Algarve, Campus de Gambelas, 8000 Faro, Portugal CASEE Center for Advanced Studies in Economics and Econometrics, Universidade do Algarve, Faro, Portugal.

jandraz@ualg.pt 


\section{SOCIAL SECURITY}

\section{AND ECONOMIC PERFORMANCE IN PORTUGAL: \\ AFTER ALL THAT HAS BEEN SAID AND DONE \\ HOW MUCH HAS ACTUALLY CHANGED?}

\section{Introduction}

It is well understood in both academic and political circles that the Portuguese social security system based on a pay-as-you-go regime is highly susceptible to financial sustainability problems and is prone to generating macroeconomic inefficiencies.

In fact, aside from the demographic problems that affect pay-as-you-go systems all over the world, in Portugal, with a still maturing social security system, sustainability concerns are greatly exacerbated by the large non-contributory coverage and the dimension of the social action programs existing side-by-side with the standard insurance-based pension coverage. In 2003, for example, non-contributory and social action expenses accounted for 53\% of total social security spending [for details see ch. 3 in Rodrigues and Pereira (2007)]. Not surprisingly, social security has been widely regarded as being financially unsustainable [see, for example, Borges and Lucena (1988), Braz, (1995), Pereira and Rodrigues (2001) and Rodrigues and Pereira (2007)].

In turn, social security spending has been financed mostly through payroll contributions, which in 2003 accounted for $63.9 \%$ of the social security revenues, the remaining coming from general tax revenues in the form or either VAT allocations or general transfers [see again ch. 3 in Rodrigues and Pereira (2007)].

There are two major corollaries of this situation. First, less than three-quarters of payroll contributions are actually being used to pay for the contributory regimes. This means that non-contributory and social action spending are in good part financed by payroll contributions, which, to the extent they are used for these purposes, can only be regarded as labor taxes. On the flip side, more than one-third of the social security revenues come from general tax revenues. This means that a large chunk of social security spending is directly financed through taxes with their inevitable distortions. 
Second, and even for the part of the social security contributions allocated to pay insurance-type benefits, historically there has been no close relationship between payroll contributions and future benefits. Therefore, social security contributions are, to a certain extent, perceived as taxes on labor income. Naturally, the insurance role of pensions does not require a perfect link between pensions and earning. However, the weaker the link the greater is the potential for contributions to be perceived as taxes and for inefficiencies to exist. To the extent that the burden of these taxes is borne by producers they increase the real unit costs of labor and adversely affect labor demand and, to the extent that it is borne by workers, they reduce disposable income and private savings and ultimately capital formation [see, for example, Evans (2001), Feldstein (1996) and Gramlich (1996), and Pereira (1998)].

Given the sustainability and efficiency problems that plague the Portuguese social security system it is hardly surprising that social security reform has been a central fixture of the economic policy debate and that several major reforms have been implemented during the last two decades. The first major reform took place in 1984 and greatly expanded the universe of beneficiaries and the generosity of the benefits codifying the changes introduced after the Revolution of April 1974 and clearly making matters worse from a sustainability standpoint. The earliest efforts to reverse this trend took place in the early 1990s with the introduction of private pension funds and a greater scrutiny of eligibility and benefits under the publicly-administered system. This was followed by major comprehensive reforms in 1993, unifying the benefits for new private and public sector workers, and in 2002, changing the way pension benefits are calculated. The most recent reform was enacted in early 2007. In all cases, the stated objective of the reforms was to alleviate the sustainability and inefficiency problems of the system while maintaining the pay-as-you-go nature of the system.

Empirical evidence suggests that all of these reforms have done very little to alleviate the financial sustainability problems. Indeed, in the context of a dynamic general equilibrium model of the Portuguese economy Rodrigues and Pereira (2007) show that the combined effects of the reforms enacted until 2002 were greatly detrimental in terms of sustainability while the reforms enacted thereafter and until 2007 were only marginally beneficial. The effects of the reforms in 2007 were only superficially addressed but preliminary analysis suggested that they represented a step in the right direction. Altogether the issue of the sustainability of the social security system in Portugal remains a matter of great concern. 
The question remains, however, as to the extent to which these reforms may have at least reduced the inefficiency effects of the system. This issue is of course important in itself since the presence of sizable distortions would suggest that reform would be important even in the absence of sustainability issues. More importantly, however, the existence of sizable inefficiencies is critical from the perspective of the design of future reforms. In fact, if distortions are sizable, the conventional recipes for dealing with sustainability are less likely to work or will work only at the cost of potentially increasing distortions. For example, increasing distortionary labor taxation would adversely affect employment and thereby induce a negative feedback on the tax base. The distortionary effects of the system would increase and sustainability problems would be reduced by less than suggested by just considering the rates of labor taxation.

The objective of this paper is to empirically determine the magnitude of the distortions induced by the social security system in Portugal and to determine the extent to which the extensive reforms over the last two decades through 2007, aiming at bringing a closer link between contributions and benefits might have improved such distortions. As in Pereira (1998), we estimate a VAR model of GDP, unit labor costs, the unemployment rate, the saving rate, and social security spending. This dynamic multivariate approach follows the conceptual argument that the analysis of the social security effects requires considering the dynamic feedback effects between changes in social security spending and changes in the other variables. In this context, all variables are treated as endogenous and social security spending affects economic performance over time but it is also affected by economic performance over time, i.e., this approach fully accommodate the possibility of reverse causality in the standard sense of Grangercausality.

\section{Data and Preliminary Results}

Is this section we present the data and perform unit root and cointegration tests as well as VAR model specification tests. Then, we discuss the identification of innovations in social security spending and the measurement of their effects. We consider GDP, the real unit cost of labor index, the unemployment rate, the private sector gross saving rate as a percentage of the GDP, and social security spending as a percentage of the GDP. No exogenous demographic variables where included in our analysis. This reflects the understanding that during the sample period efficiency issues 
were much more related to the maturing of the Portuguese social security system through discretionary changes in coverage and in the generosity of the benefits, including non-contributory schemes and social action spending, with ageing itself being less of a factor.

\subsection{Data sources and description}

We consider annual data for the period 1970 to 2007. Data for GDP was obtained from the macro-economic database of the European Commission's Directorate General for Economic and Financial Affairs-AMECO. The remaining data comes from the statistical annexes of the European Economy published by the European Commission $(1995,2008)$. The private sector gross saving rate measures the share of private savings, defined as the amount of disposable income that is not used for final consumption expenditure, on GDP and includes non-financial corporations, financial corporations, private households and non-profit institutions serving households.

Social security spending covers the full spectrum of activities of the social security system in Portugal, including the Caixa Geral de Aposentações, that is, the system for public sector employees. It comprises retirement pensions for both private and public sector employees their dependents and their survivors, as well as unfunded social benefits and social assistance programs. Our choice of social security spending as the relevant social security variable is meant to reflect the true dimension of the system and, therefore, the true dimension of its burden on the economy.

Table 1 presents some stylized facts. The ratio of social security spending to GDP averaged $10.3 \%$ over the sample period showing an increasing trend from $8.8 \%$ during the 70 s and 80 s to $12.4 \%$ over the two last decades and averaged $13.1 \%$ for the last ten years of the sample. Social security as a percentage of the GDP has increased at an annual rate of $1.24 \%$ over the sample period which hides a sharp increase in the early to middle 1970s followed by a continued and accelerating growth in the recent past.

To put things in perspective, social security spending as a fraction of the GDP in Portugal was $15.2 \%$ by the end of our sample period. Although this figure is only marginally above the EU-27 average of $15.1 \%$, it is only surpassed in Austria, Denmark, Finland, France, Greece, and Italy. More importantly, in the last decade social security spending to GDP ratios have decreased in the EU-27 as a whole as well as in most EU-27 countries, while sharply increasing in Portugal - similar increases have occurred only in Ireland, Greece, and Hungary. 
Finally, a closer look at the Portuguese data suggests the possibility of several structural changes during the sample period - the Revolution of April 1974 and the major social security reforms of 1984, 1993, and 2002. The possible existence of these structural breaks is fully incorporated into our unit roots, cointegration and VAR specification tests, as well as the VAR estimation procedures. We follow the standard procedure in the literature [see, for example, Maddala and Kim, (1998)], and consider the possible significance of four dummy variables for the relevant periods in every step of the analysis.

\subsection{Unit roots and cointegration analysis}

We start by using the ADF test to determine the order of integration of the variables. The optimal lag structure is chosen using the BIC, and deterministic components as well as structural break dummies are included when statistically significant. Test results are reported in Table 2. For the variables in log-levels, all $t$ statistics are lower in absolute value than the 5\% critical values, except in one case, where it is higher than the $5 \%$ critical value but below the $1 \%$ critical value. We therefore cannot reject the null hypothesis of a unit root in these variables. In turn, for the first differences of the log-levels, i.e. in growth rates, all $t$-statistics are greater in absolute value than the $1 \%$ critical values and, therefore, we can reject the null hypothesis of a unit root in these variables. These test results provide evidence that stationarity in growth rates is a good approximation for all variables.

We next test for cointegration using the Engle-Granger procedure, which has proven less vulnerable than the Johansen procedure to the small sample bias toward finding co-integration when it does not exist [see, for example, Gonzalo and Lee (1998) and Gonzalo and Pitarakis (1999)]. Following the standard approach, we performed five separate tests by applying the ADF $t$-test to the residuals from the regressions of each variable on the remaining four variables. This is important since it is possible that any given variable arbitrarily chosen as endogenous could enter as non-significant in the cointegration relationship. Again, the optimal lag structure is chosen using the BIC, and deterministic components as well as structural break dummies are included when they are statistically significant. The results are reported in Table 3. The $t$-statistics are lower, in absolute value, than the $1 \%$ critical values for all cases. Thus, the ADF tests cannot reject the null hypothesis of no cointegration. In addition, we also tested for cointegration between pairs of variables as well as groups of three and four variables. 
The hypothesis of no cointegration could not be rejected in the overwhelming majority of the cases. [The results are available and provided by the authors upon request].

It should be noted that the absence of cointegration is consistent with the fact that we are analyzing a social security system that is still maturing through more comprehensive coverage and more generous benefits, in a country that is still in a convergence path to EU standards. In such a case we would not expect to see a convergence of the major ratios for the economy [Similar results have been identified for Portugal in a different context. See for example, Pereira and Andraz (2005)].

\subsection{VAR specification and estimates}

We have now determined that all the variables are stationary in growth rates and that they are not cointegrated. Accordingly, we follow the standard procedure in the literature and proceed to estimate the VAR model in growth rates.

The model specification is determined using the BIC. The VAR specification has two jointly determined dimensions - the specification of the deterministic components and the possibility of structural breaks in 1974, 1984, 1993, and 2002. The results are presented in Table 4. We find that the BIC leads to the selection of a first order VAR specification with a constant and a trend and four structural breaks. This means that the proper VAR specification requires accounting for structural changes generated by the Revolution of April 1974 and the three major social security reforms of 1984, 1993, and 2002. The VAR model estimates are presented in Table 5.

\subsection{Identification of exogenous shock to social security spending}

The key methodological issue in determining the effects of social security spending is identifying shocks to social security spending that are truly exogenous, i.e., that are not contemporaneously correlated with innovations in the remaining variables. In dealing with this issue, we draw from the standard approach in the monetary policy literature [see, for example, Christiano, Eichenbaum and Evans (1996, 1998), and Rudebusch (1998)] and consider a policy function, which relates the rate of growth of social security spending to the relevant information set. The residuals from this policy function reflect the unexpected component of the growth of social security spending and are uncorrelated with innovations in the other variables.

In our estimates we assume that the relevant information set includes past but not current observations of the growth rates of the other variables. This is equivalent, in 
the context of the Choleski decomposition, to assuming that shocks in social security spending lead shocks in the other variables. As such, shocks in social security induced by the reforms, while affecting contemporaneously economic performance are not affected contemporaneously by it.

This identification strategy seems to be rather reasonable conceptually for several reasons. First, it is reasonable to assume that the private sector reacts immediately, that is within a year to innovations in social security spending decisions. Second, it also seems reasonable to assume that the public sector is unable to adjust social security spending decisions to innovations in the private-sector variables within a year. This is due to the time lags involved in information gathering and decisionmaking. This is particularly relevant since social security financing comes from payroll contributions and from general taxation revenues from the public budget which is decided and approved annually, several months in advance and which is not trivially changed throughout the year. Third, social security reforms have overwhelmingly been driven by long-term political considerations as opposed to short-term macroeconomic conditions.

It is important to clarify the nature of our identification assumption. Naturally, several components of social security spending are sensitive to the business cycle. What we observe [from sources from the Portuguese Ministry of Finance readily available online] is that the component of the social security budget that is vulnerable to the business cycle is at most about $30 \%$ of the total spending and includes mostly unemployment benefits and different types of social action spending. On the other hand, the remaining non-contributory expenditures, mostly old age, disability and survivor pensions, are subject to more rigid formulas and seem to take even longer to react to the economic performance.

At any rate, the idea of social security spending reacts to economic performance is automatically accommodated in the VAR analysis since we allow social security spending to react to the other variables with a lag of one year. The question that remains, and what is under discussion here, is the nature of contemporaneous effects, that is, effects within a year. We want to identify truly exogenous shocks in social security spending, shocks that are not contemporaneously correlated with shocks in the other variables. Here we are assuming that social security spending lead shocks in the other variables. This idea is made even more plausible empirically by the fact that only 
at most $30 \%$ of the social security budget shows vulnerability to the business cycle even after a year.

\subsection{Measuring the effects of exogenous changes in social security spending}

In measuring the effects of changes in social security spending we consider the effects of a one-time innovation in the growth rate of social security spending. The impulse-response functions associated with the VAR estimates and the policy function described above as well as the corresponding $80 \%$ error bands are presented in Figures $1-4$. We observe without exception that most of the growth rate effects occur within the first few years after the shocks occur.

The error bands surrounding the point estimates for the accumulated impulse responses convey uncertainty around estimation and are computed via bootstrapping. We consider $80 \%$ intervals although bands that correspond to a $68 \%$ posterior probability or one standard error are the standard in the literature [see, for example, Sims and Zha (1999)]. In fact, evidence exists that nominal statistical coverage distances may under represent the true statistical coverage in a variety of situations (Kilian, 1998). Employing the 80\% intervals widens the range of values that characterize the likelihood shape and only serves to statistically strengthen our results, in that even with wider margins they tend to remain on the same side of the spectrum, negative or positive.

We estimate the long-term accumulated elasticities of the different variables with respect to social security spending as the long-term accumulated changes in the different variables, for a one percent long-term accumulated change in social security spending. This is a conventional definition only in that it measures relative percentage changes. Unlike the conventional definition, however, this is a total accumulated and normalized elasticity. It is a total elasticity in that it accounts for all the dynamic feedbacks among the different variables. It is an accumulated elasticity in that it measures the long term effects as the impulse response functions converge. It is a normalized elasticity in that it measures the effects of a one percentage point change in social security spending in the long term and not a one percentage point initial shock, which through the feedback mechanisms translates into a different accumulated long term shock.

In turn, the long-term accumulated marginal products give us the percentage point change in each variable for a one percentage point change in social security 
spending as a percentage of the GDP [from $13.1 \%$ to $14.1 \%$ ]. The marginal products are obtained by multiplying the estimated accumulated long-term elasticities by the average ratio for the last ten years of the sample of the corresponding variable to social security spending as a percentage of the GDP. This allows us to interpret the marginal products as the long-term effects of social security spending under the most recent economic conditions while at the same time avoiding business cycle effects. Formally, the marginal product of $\mathrm{x}$ with respect to $\mathrm{y}$ is directly obtained from the standard definition of elasticity of $\mathrm{x}$ with respect to $\mathrm{y}$ and can be written as:

$$
\text { Marginal Product }_{\mathrm{x}, \mathrm{y}}=\text { elasticity }_{\mathrm{x}, \mathrm{y}} \cdot[\mathrm{x} / \mathrm{y}] \cdot \Delta \mathrm{y}
$$

\section{Social Security Spending and Economic Performance}

In this section we analyze the effects of social security spending with the purpose of determining first if there are significant distortions associated with the social security system and second whether or not the reforms in the last two decades have contributed to reducing such distortions. The empirical results are presented in Table 6.

\subsection{Measuring the detrimental effects of social security spending}

Our empirical results suggest that social security spending has adverse effects on the labor market in that it increases unit labor costs and the unemployment rate. The long-term elasticity of the unit cost of labor with respect to changes in social security spending is 0.31 and the elasticity of the unemployment rate is 3.84 . These values imply that an increase in the ratio of social security spending to GDP by one percentage point [from an average of $13.1 \%$ of the GDP to $14.1 \%$ ] leads to an increase of 2.40

percentage points in the index of the unit costs of labor [from an average of 101.4 to 103.8] and to a 1.70 percentage point increase in the unemployment rate [from an average of $5.8 \%$ to $7.5 \%$ ].

Our empirical results also suggest that social security spending has adverse effects on financial markets in that it reduces the savings rate. The long-term elasticity of the saving rate with respect to social security spending is -0.21 . This means that an increase of one percentage point in the ratio of social security spending to GDP leads to a reduction of the saving rate by 0.28 percentage points [from an average of $17.5 \%$ to about $17.2 \%]$. 
Finally, our empirical results suggest that social security spending has an adverse effect on GDP. The long-term elasticity of GDP with respect to social security spending is -0.38 . Considering the monetary value of an increase of a one point change in social security spending as a percentage of the GDP [from 13.1\% to 14.15] this figure implies that a one euro increase in social security spending reduces output, over the long-term, by 2.90 euros. This negative effect on long-term GDP is consistent with the adverse effects identified above on both labor and financial markets. In turn, the effects on unemployment match the positive effects on unit labor costs [a negative substitution type of effect on labor demand] and the negative effects on output [a negative scale type of effect on labor demand]

It terms of the reliability of these results as suggested by the error bands in Figures 1-4, it is important to highlight that our estimate for the effect of social security spending on the savings rate shows a range of variation that includes zero effects which reinforces the notion of a very small impact on the savings rate. As to the other variables, the ranges of variations of the effects within the $80 \%$ error bands are always on the same side of the spectrum.

\subsection{How much did things change in the last two decades?}

In order to answer the question of whether or not the inefficiencies generated by the social security system have been reduced by the reforms in the last two decades we compare the results presented in the previous section which are based on data for 19702007 with the results that would be obtained for 1970-1993. The cut off point of 1993 is suggested by the fact that this is the year of the first major reform explicitly enacted to attempt to stem the tide of increasing coverage and generosity of benefits [see Rodrigues and Pereira (2007) for details] as well as one of the statistically significant structural breaks in the VAR structure. To obtain the results for the earlier period we estimate a VAR model according to the best specification suggested by the BIC which incorporates a constant and a trend as well as a structural break in 1974.

By comparing the two sets of results we find that the adverse effects of social security on GDP are almost identical - a somewhat higher elasticity, -0.38 versus -0.30 , but virtually the same marginal product, -2.99 euros versus -2.90 euros long-term reduction in the GDP per one euro increase in social security spending. Therefore, no overall progress has been made in the last two decades. 
Some differences can be identified, however, in terms of the other margins. The adverse effects on the unit labor costs have been somewhat mitigated, $2.40 \%$ versus $3.61 \%$ increase per one percentage point increase in social security spending, while the actual effects on unemployment have been somewhat amplified, 1.70 versus 1.33 percentage point increase in the unemployment rate per one percentage point increase in social security spending. These figures overall suggest a deterioration of the labor market inefficiencies over the last two decades.

In turn, the negative effects on the savings rate have been greatly reduced, -0.28 versus -2.52 percentage point reduction per one percentage point increase in social security spending. Indeed, as we mentioned above, the effects on the savings rate for the longer period are not significantly different from zero. This suggests an improvement - indeed a virtual elimination - over the last two decades of the financial market inefficiencies induced by the social security system.

\section{Concluding Remarks}

In this paper we estimate the impact of the Portuguese social security system on economic performance over the period from 1970 to 2007 in order to measure the extent of the detrimental effects induced by a growing social security system and more importantly to evaluate whether or not the reforms undertaken over the last two decades have contributed to significantly reduce such effects.

The central message of this paper is twofold. First, our results suggest the existence of negative effects on both labor markets and financial markets, as social security spending leads to higher unit labor costs and the unemployment rate as well as to marginally lower saving rates. Naturally, the overall effect on GDP is also negative. Second, the reforms in the last two decades have not been effective in dealing with the inefficiencies of the social security system. The negative effects of social security spending on GDP remain virtually the same after the reforms and while there has been a marked improvement in the effects on savings there has been also a deterioration of the effects on unemployment.

Although international comparisons are not easy, they are not impossible. Our results are most directly comparable to the ones in Pereira and Andraz (2010), where a similar approach is applied to a group of fourteen countries, essentially the EU-12 plus Japan and the USA. In this international study, detrimental effects on employment and 
GDP are observed, although to different degrees, in all countries. The effects for Portugal identified in the current paper tend to be at the higher end of the spectrum of the international results identified there. In turn, the effects on the gross savings rate are mixed with social security spending having a positive, albeit small, effect on savings in several countries. As we have shown in this paper the effects identified for Portugal are clearly negative, this being the only truly distinguishing feature of the Portuguese case.

Our empirical results are very important from the perspective of the design of future social security reforms. Clearly, conventional parametric reform strategies focusing merely on increasing contributions or reducing benefits have neither alleviated significantly the financial sustainability issue [see Rodrigues and Pereira (2007)] nor have helped in any meaningful way with the inefficiency problems as argued in this paper.

With the projected demographic evolution into the next few decades, the accelerating ageing of the Portuguese population should be expected to greatly exacerbate both sustainability and efficiency concerns - sustainability directly through the sharp expected increases in the dependency ratios and efficiency indirectly to the extent that increased social security contributions will be used to bridge the sustainability gap. Indeed, historically, the adverse negative efficiency effects of social security in Portugal can be attributed mostly to policy decisions in the context of a relatively young and maturing system - increased coverage and increased benefits for the existing coverage. Such will not likely be the case into the next few decades, however, as an ageing population under a pay-as-you-go financing system will likely be the source of further substantial adverse efficiency effects. This highlights how seriously the current inefficiencies should be treated.

Accordingly, the time has arrived to consider structural reforms designed to shift much of the pension burden from what is known as the first pillar (the state) to the second pillar (the employer) and to the third pillar (the individual). A central piece of such reform would be changing the pay-as-you-go financing regime into a capitalization regime. Under this new financing regime the undesirable dependence on demographic evolution would not be an issue thereby eliminating or at least greatly alleviating the sustainability issues. Furthermore, contributions would not be perceived as taxes on labor income, thereby eliminating or at least greatly alleviating the inefficiency effects on savings and employment [see, for example, Bosworth and Burtless (2004a, 2004b), Coronado (2002), Meyermans (2004), Conesa and Garriga (2008) and Silva (2008)]. 
Naturally, the transition to a new financing regime would not be costless but neither is maintaining the status quo.

Even though this research presents several policy implications which are important in themselves, it also opens the doors to several important avenues for future research with equally important policy implications. First, it could be rather informative to separate contributory and non-contributory social security spending. Although both lead to inefficiencies, the sources are very different and so the corresponding magnitudes can also be very different. Indeed, it would be very useful to identify how much of the inefficiencies comes from using payroll taxes and general tax revenues to finance non-contributory and social action spending and how much comes from the fact that social security contributions may be partially perceived as taxes on labor due to the historically vague link between contributions and benefits. Second, and in a more general context this raises the issue of determining the least distortionary way of financing non-contributory and social action spending which really entails a closer look at the distortionary effects of the current tax system at the different tax margins.

\section{References}

Borges, A. and D. Lucena (1988). "Social Security in Portugal: A System in Disequilibrium", in Nova Economia em Portugal, Alfredo de Sousa (Ed.). Universidade Nova de Lisboa, Portugal.

Bosworth, B. and G. Burtless (2004a). "Supply-Side Consequences of Social Security Reform: Impact on Savings and Employment," Center for Retirement Research at Boston College Working Paper 2004-01.

Bosworth, B. and G. Burtless (2004b). "Pension Reform and Saving," National Tax Journal 57 (3), 703-28.

Braz, J. (1995). Dívida Implícita da Segurança Social, Instituto de Seguros de Portugal, Portugal.

Christiano, L., M. Eichenbaum, C. Evans (1996). “The Effects of Monetary Policy Shocks: Evidence from the Flow of Funds," Review of Economics and Statistics 78(1), 16-34. 
Christiano, L., M. Eichenbaum and C. Evans (1998). "Monetary Policy Shocks: What Have we Learned and to What End?" National Bureau of Economic Research Working Paper 6400.

Conesa, J. and C. Garriga (2008). "Optimal Fiscal Policy in the Design of Social Security Reforms," International Economic Review 49 (1), 291-318.

Coronado, J. L. (2002). "The Effects of Social Security Privatization on Household Saving: Evidence from Chile," Contributions to Economic Analysis and Policy 1(1) Article 7.

European Commission (1995). European Economy - Statistical Annex. Brussels. European Commission (2008). European Economy - Statistical Annex. Brussels.

Evans, Paul (2001). "Consumer Behavior in the United States: Implications for Social Security Reform,” Economic Inquiry 39, 568-82.

Feldstein, M. (1996). "Social Security and Savings: A New Time Series Evidence," National Tax Journal 49, 151-64.

Gonzalo, J. and J. Pitarakis (1999). "Dimensionality Effect in Cointegration Analysis," in Festschrift in Honor of Clive Granger, R. Engle and H. White (Eds.), Oxford University Press.

Gonzalo, J. and T. Lee (1998). "Pitfalls in Testing for Long-Run Relationships," Journal of Econometrics 86, 129-54.

Gramlich, E. (1996). "How Does Social Security Affect the Economy?" in Social Security in the $21^{\text {st }}$ Century, E. Kingson and J. Schultz (Eds). New York: Oxford University Press.

Kilian, L. (1998). "Small-Sample Confidence Intervals for Impulse Response Functions," Review of Economics and Statistics 80 (2), 218-30.

Maddala, G. and I. Kim (1998). Unit roots, Cointegration and Structural Change, Cambridge University Press, Cambridge.

Meyermans, E. (2004). “The Macro-economic Effects of Labor Market Reforms in the European Union," Federal Planning Bureau Working Paper 12-04, Brussels.

Pereira, A. (1998). "Social Security and Economic Performance in Portugal," Economic Bulletin of the Bank of Portugal 4 (2), 57-68. 
Pereira, A. and J. Andraz (2005). "Public Investment in Transportation Infrastructures and Economic Performance in Portugal," Review of Development Economics 9, 177-196.

Pereira, A. and J. Andraz (2010). "Social Security and Economic Performance: International Evidence," mimeo.

Pereira, A. and P. Rodrigues (2001). "Koureinami in Portugal: A Tale of Aging and the Sustainability of the Public Pension Schemes," mimeo

Rodrigues, P. and A. Pereira (2007). A Reforma das Pensões em Portugal: Uma Análise de Equilíbrio Geral Dinâmico. Fundação Luso-Americana, Lisboa, Portugal.

Rudebusch, G. (1998). "Do Measures of Monetary Policy in a VAR Make Sense?" International Economic Review 39, 907-31.

Silva, A. (2008). "Taxes and Labor Supply: Portugal, Europe, and the United States," Portuguese Economic Journal 7 (3), 101-24.

Sims, C. and T. Zha (1999). "Error Bands for Impulse Responses," Econometrica 67 (5), 1113-55. 
Table 1: Main stylized facts of social security transfers

\begin{tabular}{ccc}
\hline Periods & $\begin{array}{c}\text { Social Security Spending } \\
\text { as percentage of GDP }\end{array}$ & $\begin{array}{c}\text { Growth of } \\
\text { Social Security Spending } \\
\text { as percentage of GDP }\end{array}$ \\
\hline $\mathbf{1 9 7 0 - 0 7}$ & 10.31 & 1.24 \\
\hline $\mathbf{1 9 7 0 - 9 1}$ & 8.82 & 1.29 \\
$\mathbf{1 9 9 2 - 0 7}$ & 12.35 & 1.15 \\
\hline $\mathbf{1 9 7 0 - 7 3}$ & 6.03 & 2.68 \\
$\mathbf{1 9 7 4 - 7 5}$ & 8.00 & 14.24 \\
$\mathbf{1 9 7 6 - 8 4}$ & 9.47 & 0.40 \\
$\mathbf{1 9 8 5 - 9 3}$ & 9.99 & 0.53 \\
$\mathbf{1 9 9 4 - 0 2}$ & 11.43 & 0.79 \\
$\mathbf{2 0 0 3 - 0 7}$ & 14.72 & 1.26 \\
\hline
\end{tabular}

Table 2: ADF Unit roots tests

\begin{tabular}{|c|c|c|c|c|c|}
\hline \multirow{2}{*}{ Variables } & \multirow{2}{*}{$\begin{array}{l}\text { Determinist } \\
\text { components }\end{array}$} & \multirow{2}{*}{$\begin{array}{l}\text { Order } \\
\text { (BIC) }\end{array}$} & \multirow{2}{*}{$\begin{array}{c}\text { Test } \\
\text { statistic }\end{array}$} & \multicolumn{2}{|c|}{ Critical values } \\
\hline & & & & $5 \%$ & $1 \%$ \\
\hline \multicolumn{6}{|l|}{ Log levels of ... } \\
\hline GDP & $\mathrm{CT}$ & 1 & -3.6197 & -3.50 & -4.15 \\
\hline Gross Savings Rate & $\mathrm{CT}$ & 1 & -3.4550 & -3.50 & -4.15 \\
\hline Unemployment Rate & $\mathrm{C}$ & 0 & -2.0389 & -2.93 & -3.58 \\
\hline Unit Cost of Labor & $\mathrm{CT}$ & 1 & -3.1118 & -3.50 & -4.15 \\
\hline Social Security Spending & $\mathrm{CT}$ & 0 & -2.8992 & -3.50 & -4.15 \\
\hline \multicolumn{6}{|l|}{ Growth rates of ... } \\
\hline GDP & $\mathrm{C}$ & 3 & -4.2797 & -2.93 & -3.58 \\
\hline Gross Savings Rate & $\mathrm{N}$ & 2 & -5.0233 & -1.95 & -2.62 \\
\hline Unemployment Rate & $\mathrm{N}$ & 0 & -4.9666 & -1.95 & -2.62 \\
\hline Unit Cost of Labor & $\mathrm{N}$ & 1 & -5.1304 & -1.95 & -2.62 \\
\hline Social Security Spending & $\mathrm{C}$ & 0 & -5.7235 & -2.93 & -3.58 \\
\hline
\end{tabular}


Table 3: Engle-Granger cointegration tests

\begin{tabular}{lccc}
\hline Log levels of ... & $\begin{array}{c}\text { Deterministic } \\
\text { components }\end{array}$ & $\begin{array}{c}\text { Order } \\
\text { (BIC) }\end{array}$ & Test statistic \\
\hline GDP & CT & 0 & -2.5354 \\
Gross Savings Rate & CT & 0 & -3.5999 \\
Unemployment Rate & C & 0 & -2.5947 \\
Unit Cost of Labor & CT & 0 & -3.6453 \\
Social Security Spending & CT & 0 & -3.5235 \\
\hline
\end{tabular}

Table 4: VAR specification

\begin{tabular}{|c|c|}
\hline Deterministic Components & BIC \\
\hline \multicolumn{2}{|l|}{ No dummies } \\
\hline Constant, no trend & -36.81882 \\
\hline Constant and trend & -36.88617 \\
\hline \multicolumn{2}{|l|}{ Dummy 1974-75 } \\
\hline Constant, no trend & -38.09972 \\
\hline Constant and trend & -38.41892 \\
\hline \multicolumn{2}{|l|}{ Dummies 1974-75 and 1985} \\
\hline Constant, no trend & -38.48698 \\
\hline Constant and trend & -38.78496 \\
\hline \multicolumn{2}{|l|}{ Dummies 1974-75 and 1994} \\
\hline Constant, no trend & -38.32355 \\
\hline Constant and trend & -38.58666 \\
\hline \multicolumn{2}{|l|}{ Dummies 1974-75 and 2003} \\
\hline Constant, no trend & -38.32477 \\
\hline Constant and trend & -38.78446 \\
\hline \multicolumn{2}{|l|}{ Dummies 1974-75, 1985 and 1994} \\
\hline Constant, no trend & -38.62934 \\
\hline Constant and trend & -39.06216 \\
\hline \multicolumn{2}{|l|}{ Dummies 1974-75, 1985 and 2003} \\
\hline Constant, no trend & -38.80811 \\
\hline Constant and trend & -39.07358 \\
\hline \multicolumn{2}{|l|}{ Dummies 1974-75, 1994 and 2003} \\
\hline Constant, no trend & -38.49383 \\
\hline Constant and trend & -39.11773 \\
\hline \multicolumn{2}{|c|}{ Dummies 1974-75, 1985, 1994 and 2003} \\
\hline Constant, no trend & -38.87967 \\
\hline Constant and trend & -39.71795 \\
\hline
\end{tabular}


Table 5: VAR model estimates

\begin{tabular}{|c|c|c|c|c|c|}
\hline Growth rates of ... & GDP & $\begin{array}{c}\text { Gross } \\
\text { Savings } \\
\text { Rate } \\
\end{array}$ & $\begin{array}{c}\text { Unemployment } \\
\text { Rate }\end{array}$ & $\begin{array}{l}\text { Unit Cost of } \\
\text { Labor }\end{array}$ & $\begin{array}{c}\text { Social } \\
\text { Security } \\
\text { Spending }\end{array}$ \\
\hline Constant & $\begin{array}{c}0.0247^{*} \\
(4.26)\end{array}$ & $\begin{array}{c}0.0738^{* *} \\
\quad(1.88)\end{array}$ & $\begin{array}{c}0.1529^{*} \\
(2.59)\end{array}$ & $\begin{array}{c}-0.0125^{* *} \\
(-1.72)\end{array}$ & $\begin{array}{c}0.0388^{*} \\
(2.99)\end{array}$ \\
\hline Trend & $\begin{array}{c}-0.0019^{*} \\
(-4.03)\end{array}$ & $\begin{array}{c}-0.0068^{*} \\
(-2.09)\end{array}$ & $\begin{array}{c}-0.0015 \\
(-0.31)\end{array}$ & $\begin{array}{c}0.0004 \\
(0.72)\end{array}$ & $\begin{array}{c}-0.0009 \\
(-0.88)\end{array}$ \\
\hline Dummy 75 & $\begin{array}{c}-0.0365^{*} \\
(-5.12)\end{array}$ & $\begin{array}{c}-0.2110^{*} \\
(-4.37)\end{array}$ & $\begin{array}{c}0.0282 \\
(0.39)\end{array}$ & $\begin{array}{c}0.0662^{*} \\
(7.45)\end{array}$ & $\begin{array}{c}0.0304^{* *} \\
(1.91)\end{array}$ \\
\hline Dummy 85 & $\begin{array}{c}0.0204^{*} \\
(3.69)\end{array}$ & $\begin{array}{c}0.0659^{* *} \\
(1.75)\end{array}$ & $\begin{array}{c}-0.0699 \\
(-1.24)\end{array}$ & $\begin{array}{c}0.0007 \\
(0.10)\end{array}$ & $\begin{array}{c}-0.0104 \\
(-0.84)\end{array}$ \\
\hline Dummy 94 & $\begin{array}{c}0.0164^{*} \\
(3.04)\end{array}$ & $\begin{array}{c}0.0344 \\
(0.94)\end{array}$ & $\begin{array}{c}0.0124 \\
(0.22)\end{array}$ & $\begin{array}{c}-0.0005 \\
(-0.07)\end{array}$ & $\begin{array}{c}0.0124 \\
(1.03)\end{array}$ \\
\hline Dummy 03 & $\begin{array}{c}0.0085 \\
(1.59)\end{array}$ & $\begin{array}{c}0.0387 \\
(1.07)\end{array}$ & $\begin{array}{c}0.0593 \\
(1.09)\end{array}$ & $\begin{array}{c}-0.0022 \\
(-0.32)\end{array}$ & $\begin{array}{c}0.0290^{*} \\
(2.43)\end{array}$ \\
\hline GDP(-1) & $\begin{array}{c}0.5373^{*} \\
(4.11)\end{array}$ & $\begin{array}{c}0.1161 \\
(0.13)\end{array}$ & $\begin{array}{c}-4.1176^{*} \\
(-3.09)\end{array}$ & $\begin{array}{c}-0.1019 \\
(-0.63)\end{array}$ & $\begin{array}{c}-0.3661 \\
(-1.26)\end{array}$ \\
\hline Gross Savings Rate (-1) & $\begin{array}{c}0.0519 \\
(1.66)\end{array}$ & $\begin{array}{c}-0.1534 \\
(-0.72)\end{array}$ & $\begin{array}{c}-0.0021 \\
(-0.01)\end{array}$ & $\begin{array}{c}-0.0099 \\
(-0.25)\end{array}$ & $\begin{array}{c}0.0336 \\
(0.48)\end{array}$ \\
\hline Unemployment Rate (-1) & $\begin{array}{c}0.0048 \\
(0.24)\end{array}$ & $\begin{array}{c}0.2096 \\
(1.54)\end{array}$ & $\begin{array}{c}-0.1846 \\
(-0.90)\end{array}$ & $\begin{array}{c}-0.0595^{*} \\
(-2.36)\end{array}$ & $\begin{array}{c}-0.1562^{*} \\
(-3.49)\end{array}$ \\
\hline Unit Cost of Labor (-1) & $\begin{array}{c}0.2257^{* *} \\
(1.87)\end{array}$ & $\begin{array}{c}-0.4571 \\
(-0.56)\end{array}$ & $\begin{array}{c}3.0741^{*} \\
(2.51)\end{array}$ & $\begin{array}{c}0.1563 \\
(1.04)\end{array}$ & $\begin{array}{c}1.0501^{*} \\
(3.92)\end{array}$ \\
\hline Social Security (-1) & $\begin{array}{c}0.0624 \\
(0.69)\end{array}$ & $\begin{array}{c}-0.2829 \\
(-0.46)\end{array}$ & $\begin{array}{c}-1.4169 \\
(-1.55)\end{array}$ & $\begin{array}{c}0.1033 \\
(0.92)\end{array}$ & $\begin{array}{c}-0.3455^{* *} \\
(-1.72)\end{array}$ \\
\hline
\end{tabular}

Notes: t-statistics in parenthesis; ${ }^{*}$ Significant at 5\%.; ${ }^{* *}$ Significant at $10 \%$.

Table 6: Long term effects of changes in social security spending

\begin{tabular}{|c|cc|cc|}
\hline & Estimates for 1970-2007 & \multicolumn{2}{|c|}{ Estimates for 1970-1993 } \\
\cline { 2 - 5 } & Elasticities & $\begin{array}{c}\text { Marginal } \\
\text { products }\end{array}$ & Elasticities & $\begin{array}{c}\text { Marginal } \\
\text { products }\end{array}$ \\
\hline Unit Cost of Labor & 0.31 & 2.40 & 0.33 & 3.61 \\
Unemployment Rate & 3.84 & 1.70 & 1.90 & 1.33 \\
Gross Savings Rate & -0.21 & -0.28 & -0.96 & -2.52 \\
GDP & -0.38 & -2.90 & -0.30 & -2.99 \\
\hline
\end{tabular}


Figure 1: Accumulated Impulse Response of the Unit Cost of Labor to Social Security Spending

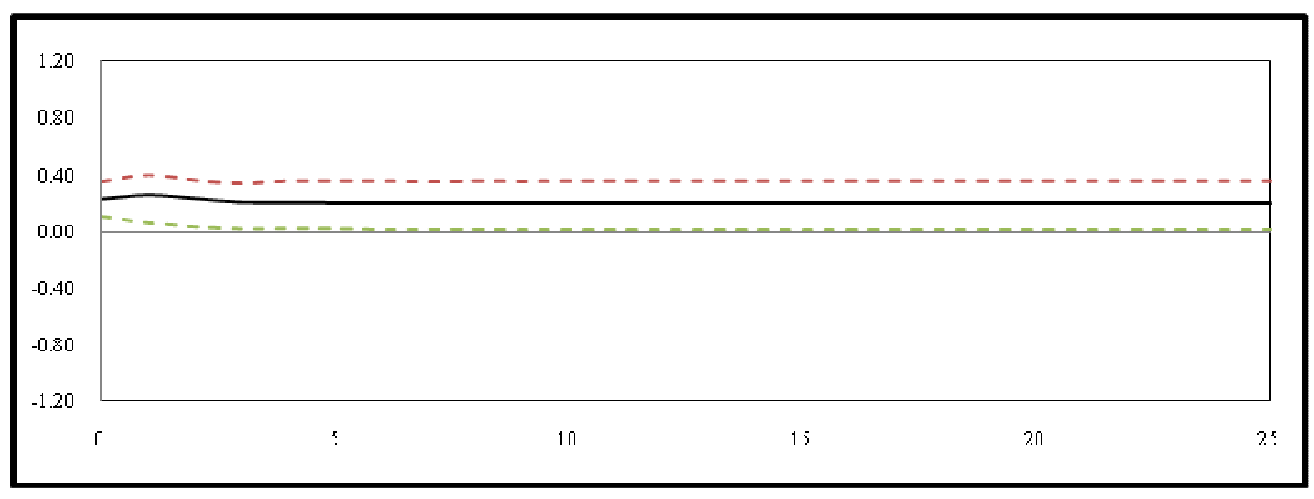

Figure 2: Accumulated Impulse Response of the Unemployment Rate to a Shock to Social Security Spending

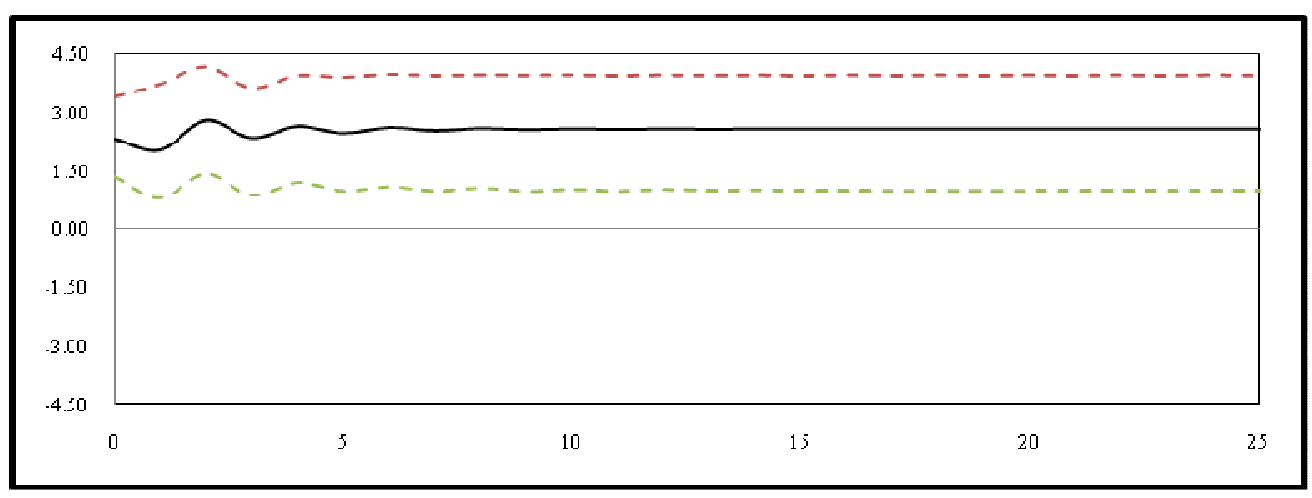

Figure 3: Accumulated Impulse Response of the Savings Rate to a shock to Social Security Spending

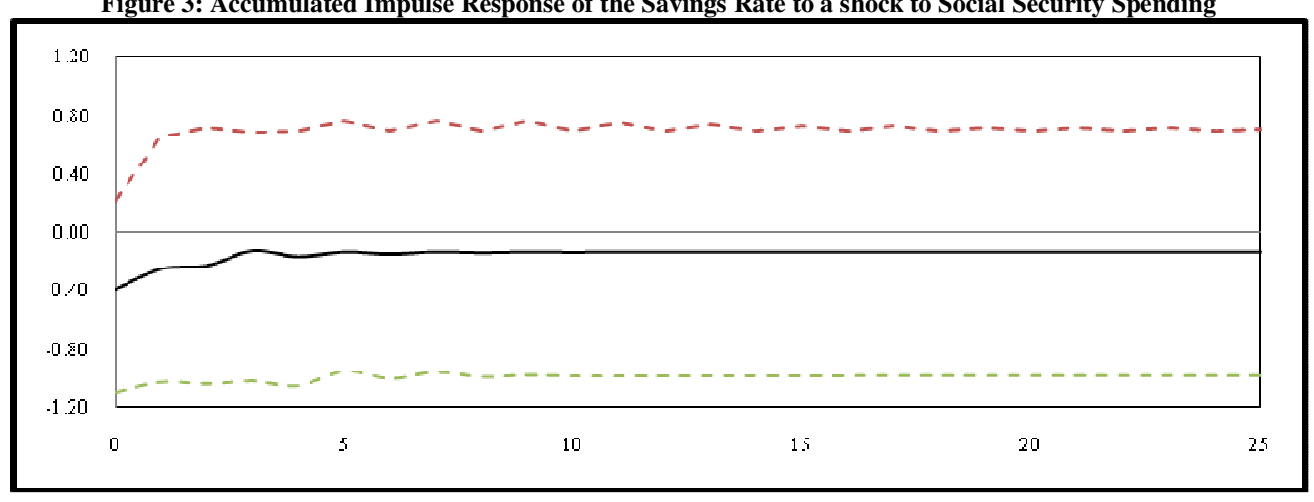

Figure 4: Accumulated Impulse Response of GDP to a shock to Social Security Spending

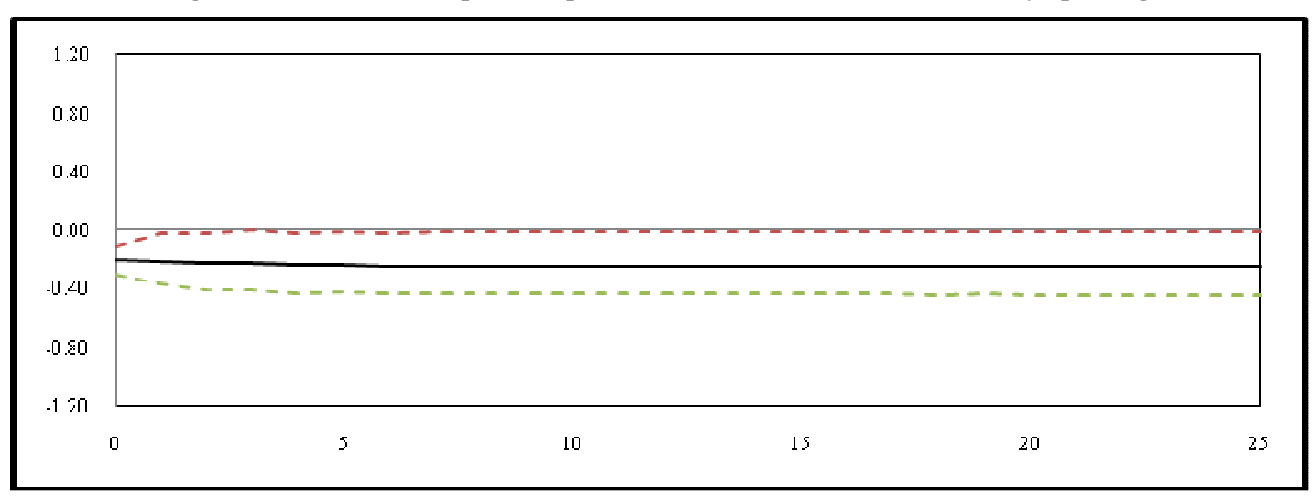

